\title{
Stimulation of vegetation growth on raised coastal fore-dune ridges
}

W. H. van der Putten and W. J. M. van Gulik (Institute for Ecological Research, Department of Dune Research 'Weevers' Duin', Duinzoom 20a, 3233 EG Oostvoorne, Netherlands)

Received 5 January 1987; accepted 13 February 1987

Abstract. Experiments were carried out to reduce the time between the planting of marram grass (Ammophila arenaria (L.) Link) and the establishment of a vegetation cover that protects the surface of coastal fore-dune ridges against wind erosion. Marram grass was planted in different ways, and was sown in combination with methods to fix the sandy surface. A newly developed method, 'sowing' marram rhizomes, was tried out in field experiments. In combination with slow-release NPK fertilizer, this method resulted within one year in a dense vegetation cover.

Key words: Ammophila arenaria, marram grass, coastal fore-dune ridge, sand fixation, rhizomes, fertilization.

Introduction. Marram grass (Ammophila arenaria (L.) Link) is the most important sand-catching and stabilizing plant species that colonizes the coastal sand dunes of Western Europe, Mediterranean countries, and Australia (Huiskes, 1979). In its natural environment, marram grass always dominates the vegetation. Marram grass is planted on artificially created sand dunes in order to establish a vegetation cover that stabilizes the sand surface. The establishment of a surface-protecting vegetation cover has proven to be a time-consuming process. The research described in this paper was initiated in order to reduce the time between the planting of marram grass and the establishment of an effective vegetation cover on artificially constructed coastal sand dunes. Experiments were carried out in order to improve traditional planting methods, to develop new planting methods, and to investigate the effect of sowing marram grass. Furthermore, fertilization experiments were carried out with both conventional and slow-release (Osmocote) NPK fertilizers.

Materials. Experiments were carried out on three experimental fields situated on the outer coastal dune ridge at Rockanje $(51.52 \mathrm{~N}, 4.05 \mathrm{E})$, Brielse Gatdam $(51.55 \mathrm{~N}, 4.05 \mathrm{E})$ and Ouddorp $(51.49 \mathrm{~N}, 3.56 \mathrm{E})$. Both fields at Rockanje and Brielse Gatdam were situated on dredged sand of sea-floor origin from the fore side of the isle of Voorne. Half the experimental field at Ouddorp was situated on sea sand, the other half was dredged sand from Haringvliet, a former tidal zone with brackish water. Plant material and seed of $A$. arenaria were collected from the dune 
area on the isle of Voorne. Seeds of other plant species of commercial origin were also sown: perennial ryegrass (Lolium perenne), Italian ryegrass (Lolium multiflorum), wheat (Triticum aestivum), barley (Hordeum vulgare), cereal rye (Secale cereale), lupine (Lupinus perennis), white clover (Trifolium repens), and a mixture of 10 species including wheat, barley, perennial ryegrass, red clover (Trifolium pratense), tall fescue (Festuca arundinacea), meadow-grass (Poa pratensis), red fescue (Festuca rubra), and fodder radish (Raphanus sativus).

Methods. The research described in this paper was set up to find out which planting method was the most successful, as well as to establish which method of sand fixation prevented the marram seed from being blown away. Furthermore the best method of sowing marram rhizomes was worked out.

Planting methods. In November 1984, marram grass was planted in bundles of 6 ramets at a spacing of $70 \mathrm{~cm} \times 100 \mathrm{~cm}$ in three different ways (experimental field Ouddorp): vertically (the traditional method), obliquely (the rhizomes were placed horizontally and the sprouts upwards; Hobbs et al., 1984), and horizontally (both rhizomes and sprouts were spread out and covered with a $15-\mathrm{cm}$ thick layer of sand). Per treatment 4 random plots $\left(4.2 \mathrm{~m}^{2} / \mathrm{plot}\right)$ were examined. These plots were all fertilized with 84-33-33 kg NPK per ha (conventional fertilizer).

Sowing of marram grass. In May 1984 , marram seed $(20 \mathrm{~kg} / \mathrm{ha} ; 1000$-grain weight $3.44 \mathrm{~g}$; germination percentage 95 ) was sown in combination with the other species mentioned above. The sand surface was stabilized by means of straw (disc-harrowed at $5000 \mathrm{~kg} / \mathrm{ha}$ ), compost (40 $000 \mathrm{~kg} / \mathrm{ha}$ ), carboxymethylcellulose (CMC, type 'average viscosity' $40 \mathrm{~kg} / \mathrm{ha}$ ) or reed (planted in bundles at a spacing of $50 \mathrm{~cm} \times$ $75 \mathrm{~cm}$ ). Marram grass was sown on the experimental field at Rockanje. The treatments were distributed according to a Latin square design.

'Sowing' of marram rhizomes. Rhizomes of marram grass, bearing dormant buds, were disc-harrowed at a depth of $10-15 \mathrm{~cm}$ (experimental field Brielse Gatdam). The disc-harrow cut the rhizomes into $15-\mathrm{cm}$ pieces, with $2-5$ dormant buds. Such pieces have proven to be most successful in surviving and in producing new plants (Maun, 1984). The rhizomes were sown at a density of $60 / \mathrm{m}^{2}$. Slow-release fertilizer (Osmocote, $80-20-20 \mathrm{~kg}$ NPK per ha) was added. Five random plots $\left(1 \mathrm{~m}^{2} / \mathrm{plot}\right)$ were examined per treatment.

Fertilization experiments. Marram dunes are poor in nutrients, especially nitrogen (Willis, 1965; Lux, 1965). Slow-release NPK fertilizers (Oscomote, 9-12 months active) were used to stimulate the development of marram plantings on the experimental field Brielse Gatdam. Per treatment 12 random bundles were examined. Since the establishment of Ammophila on a sandy dune soil without application of fertilizers is very poor, treatments without fertilizers were not examined.

Method of evaluation. Numbers of produced tillers per bundle, and seedlings per square metre were counted in order to evaluate the effect of various treatments. The results were statistically analysed with ANOVA after testing of $F_{\max }$. 


\section{Results and discussion.}

Planting ramets. Nine months after planting, the obliquely planted marram grass produced significantly more tillers per $\mathrm{m}^{2}$ than vertically planted marram (241 and 80 , respectively; $P<0.05$ ). The production of tillers by horizontally planted marram was not significantly different $\left(170 / \mathrm{m}^{2} ; P<0.05\right)$ from the other planting methods.

Sowing marram seed. The germination of marram seed was poor. In August 1984, 35 seedlings $/ \mathrm{m}^{2}$ were counted on plots with sand-surface fixation and 15 seedlings $/ \mathrm{m}^{2}$ on plots without surface fixation. By November 1984, less than half of these seedlings were left. After the winter period a flush in germination (160 seedlings $/ \mathrm{m}^{2}$ ) occurred on plots that were fixed by means of straw. Since no seedlings emerged on the plots that were stabilized by means of compost, CMC, reed, grasses, cereals and legumes, it has to be concluded that the seed was blown away because these applications did not stabilize the sand surface adequately for at least one year. The seeds of the other plant species germinated within two weeks after sowing on the plots that were stabilized, but after the winter period no plants remained. These species are therefore not worthwhile for long-term sand stabilization.

In laboratory experiments, percentage and rate of germination appeared to be enhanced after a cold humid period. Germination of untreated seed appeared to be $90 \%$ after 130 days ( 16 hours dark at $8{ }^{\circ} \mathrm{C}, 8$ hours light at $21^{\circ} \mathrm{C}$ ). Five weeks of storage at $4{ }^{\circ} \mathrm{C}$ resulted in $90 \%$ germination within $15-20$ days at the same daily temperature. Apparently, the results of sowing experiments can be improved by pretreating the marram seed.

Sowing marram rhizomes. Disc-harrowing marram rhizomes into a bare sand surface in combination with slow-release NPK fertilizer resulted in a sand surface covered with 43-67 marram tillers $/ \mathrm{m}^{2}$ within one year. It turned out that the soil surface had to be fixed by means of straw or reed in order to prevent the sand from drifting away before the marram sprouts emerged. The sowing of rhizomes to obtain a sandstabilizing vegetation is a new method developed during the research described in this paper.

Fertilizers. Application of slow-release NPK fertilizers resulted in an increased production of tillers of planted marram: $90-20-20 \mathrm{~kg}$ NPK per ha resulted into 1.7 times more tillers than 45-10-10 kg NPK per ha (both Osmocote). Since slow-release fertilizers are hardly susceptible to leaching, fertilization can be combined with planting or sowing marram grass which is carried out from October till April.

The research work is being continued in a large-scale field experiment in order to compare the most successful planting and sowing methods. Combinations of planting ramets and sowing rhizomes will also be examined. The results will be published in a subsequent paper.

Acknowledgements. Thanks are due to the Water and Civil Board De Brielse Dijkring and the Department of Roads and Waterways for financing the research work, and to C. van Dijk, D. van der Laan and S. R. Troelstra for their critical suggestions and encouragement. 


\section{References}

Hobbs, R. J., C. H. Gimingham \& W. T. Band, 1984. The effects of planting technique on the growth of Ammophila arenaria (L.) Link and Elymus arenarius (L.) Hochst. Journal of Applied Ecology 20: 659-672.

Huiskes, A. H. L., 1979. Biological flora of the British isles: Ammophila arenaria (L.) Link (Psamma arenaria (L.) Roem et Schult, Calamagrostis arenaria (L.) Roth). Journal of Ecology 67: 363-382.

Lux, H., 1965. Flugzeugeinsatz zur Düngung der Amrumer Dünen. Wasser and Boden 12: 387-390.

Maun, M. A., 1984. Colonizing ability of Ammophila breviligulata through vegetative regeneration. Journal of Ecology 72: 565-574.

Willis, A. J., 1965. The influence of mineral nutrients on the growth of Ammophila arenaria. Journal of Ecology 53: 735-745.

This synopsis is based on part of a report entitled 'Stimulering van begroeiing van nieuw opgehoogde zeewerende duinen', Institute for Ecological Research, Department of Dune Research 'Weevers' Duin', Oostvoorne, 1985. 86 pp., 57 figs., 6 tables, 69 refs. Dutch, English summary and English legends to tables and figs.

Available as paper copy (order R071P, $f 20$ including postage) or microfiche (order R071M, f 12.50 including postage) at: NARD, clo Pudoc, P.O. Box 4, 6700 AA Wageningen, Netherlands (telex 45015 blhwg). 